\title{
Conference roundup
}

\section{ATD International Conference and Expo 2020}

The ATD International Conference and Expo 2020 takes place May 17-20 at the Colorado Convention Center, Denver, Colorado https://atdconference.td.org/

There are over 12,000 attendees expected, along with over 400 speakers, more than 300 sessions and over 400 exhibitors. There are a number of learning tracks at this year's event, including:

- Career development

- Evaluating impact

- Global perspectives

- Instructional design

- Leadership development

- Learning sciences

- Learning technologies

- Management

- Managing the learning function

- Sales enablement

- Talent and strategy management

- Training delivery and facilitation

- Government

- Healthcare

- Higher education

The event features preconference learning, general sessions, a networking night, and a range of keynote speakers, one of those is Sir Richard Branson.

\section{CIPD Festival of Work}

The annual CIPD Festival of Work takes place June 10-11 at Olympia London, UK wnw. festivalofwork.com/. The Festival of Work is more than a conference and exhibition; it is an opportunity for attendees to get immersed into a world of inspiration and discovery. Attendees can explore new viewpoints and ideas, while exploring how learning, technology and innovation can come together, to shape remarkable workplaces that put people first. Keynote speakers include:

- Caroline Criado-Perez

- John Amaechi

- Professor Dame Carol Black

- Andy Briggs

And many more. 